International Journal of Instruction

e-ISSN: 1308-1470 • www.e-iji.net
July $2017 \bullet$ Vol.10, No.3

p-ISSN: 1694-609X

pp. $1-14$

Received: 20/02/2017

Revision: 04/04/2017

Accepted: 10/04/2017

\title{
Students' Satisfaction with the Group Work Method and its Performance Evaluation: A survey in an Italian University
}

\author{
Massimo Zedda \\ Università di Torino, Dep. of Psychology, Italia,massimo@zedda.it
}

\section{Silvia Bernardelli}

Università di Torino, Dep. of Psychology, Italia, bernardelli.slv@gmail.com

\section{Daniela Acquadro Maran}

Asst. Prof., Università di Torino, Dep. of Psychology, Italia, daniela.acquadro@unito.it

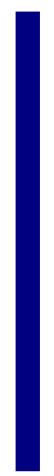

\begin{abstract}
Group Work Learning Method is a cooperative learning technique that has positive effects in learning: students' active participation can increase both cognitive and social skills. Our work involved three cohorts of students of different years attending the same course at the University of Torino, Department of Psychology. The contents of the course were the same in all years, students were asked to form self-selected groups to find creative solutions to two cases regarding violent behavior in workplace. Satisfaction concerning this activity and the method to evaluate the performance of the activity were investigated. Findings confirm overall students' satisfaction related to group work learning method. This satisfaction improves the scores in course and teacher skills satisfaction. About the evaluation, findings shown that students agreed teacher's and peers' evaluation of the performance.
\end{abstract}

Keywords: satisfaction, evaluation, participation, psychology, learning, Italy

\section{INTRODUCTION}

In recent years, the group work learning method has been introduced in graduate and undergraduate programs as a teaching method that integrates the traditional face-to-face class. Several investigations have examined similar approaches in pre-school, high school and university courses such as science and English secondary classrooms (see, e.g., MacQuarrie, Howe \& Boyle, 2012), IT (Joyce \& Elliot, 2007), economic (Leeds, Stull \& Westbrook, 1998), accountability (Bonanno, Jones \& English, 1998), medical school (Kamin, O’Sullivan, Deterding \& Younger, 2003), and social studies (Salako, Eze \& Adu, 2013).

Group work is a cooperative learning method (Sullivan \& Wilson, 2015). Group work is more than simply working side by side with group members, helping each other and

Citation: Zedda, M., Bernardelli, S. \& Maran, D. A. (2017). Students' Satisfaction with the Group Work Method and its Performance Evaluation: A survey in an Italian University. International Journal of Instruction, 10(3), 1-14. https://doi.org/10.12973/iji.2017.1031a 
discussing and sharing materials, although these are important factors. Members of a group have clear and positive interdependence, and they work together on a common goal. While sharing their knowledge and success with colleagues, they pay attention to each other and are responsible for their own contributions to group work. They must use their interpersonal skills in positive ways in order to promote individual accountability and to achieve group goals (Johnson \& Johnson, 1992; MacQuarrie et al., 2012; Lee, 2013; Salako et al., 2013). In their meta-analysis, Johnson, Johnson and Stanne (2000) argue that group work is one of the cooperative learning methods that permits to maximize the students' learning. Group work was considered as an instructional strategy that use the sharing of knowledge, the cooperation in performing a task, the social interaction to enhance the quality of the learning (Johnson, Johnson \& Smith, 2014).

One question about this method asks whether it is satisfactory for students. The need to measure student satisfaction has received attention in higher education due to the positive benefits associated with e.g. higher retention rates, recommendation to other to study in the same institution, intention to study at a higher level in the same institution (Tessema, Ready \& Yu, 2012). On the other hand, dissatisfaction was related to the intention to quit or transfer in other institutions and a negative image for the community and future applicants (Pedro, Leitão \& Alves, 2016). Consequently, in the context of higher education the satisfaction expressed by students has become an important indicator of teaching quality (Moore, 2006). Supplementary teaching activities (such as group work) are considered as one of the factors that could affect the students' satisfaction (Letcher \& Neves, 2010). As argued by Pang and Hung (2016), satisfaction for group work reflects the level of affective response that individual holds towards the experience. Moreover, the level of satisfaction expressed by individual suggests how the group work and its performance satisfied members' needs.

Another important factor that affects the satisfaction with the group work learning method is how students' performance is evaluated (by teacher and/or peers). In their study, Joyce and Elliot (2007) found that students considered teachers lacking of expertise at assigning grades because they were unaware of the real contribution of each member to the project, as Blackshaw and Latu (2005) highlighted in a previous study. In order to address this problem, the authors suggested introducing other techniques, such as peer evaluation. In an investigation conducted by Topping (2003, 2010), findings showed that evaluation of performance by peers could help students to identify their own strengths and weaknesses, and that feedbacks could be used to propose remedial actions and develop transferable professional skills. The author underlined that other transferable professional skills, such as being motivated to respond to feedbacks and showing respect for the work performed by the group, are also important for students to learn. Therefore, the questions about how to evaluate the performance of the group, who must be evaluated and by whom are critical (Elliot \& Higgins, 2005).

Given the pedagogical value of this method, the understanding of what affects the students' satisfaction in group work and its evaluation permit teachers to improve the method and the ability to manage the group work in the classroom. 


\section{Current study}

The aim of this study was to investigate students' satisfaction with the group work learning method and the evaluation of the performance. This method was used for three subsequent years in the "Psychology of Mobbing, Harassment and Stalking" course in the Department of Psychology at the Università di Torino. The curriculum consists of both bachelor's degree courses (total number of credits: 180) and master's degree courses (total number of credits: 120). This study was conducted in a master's degree course that dispenses six credits per 30 hours (two sessions per week, five weeks of sessions). The variables analyzed in the literature to build the group work (group work size, duration of the group work, how the group is constituted) and the evaluation of the group performance were considered. The variables are:

1. Number of members: as suggested by Joyce and Elliot (2007), the decision was made to include between four and eight members in each group.

2. Duration of the group: due to the time schedule of University courses (determined by the time table for class sessions and other pedagogical activities), we decided to use short-term groups. This means that the duration of the group followed the duration of the course (five weeks). Students were invited to complete their projects in class and (if necessary) during others periods of time. This allowed the groups to concentrate on their tasks and goals (Bradley, White \& Mennecke, 2003).

3. The process of defining the group: according to Hamlyn-Harris, Hurst, Von Baggo \& Bayley (2006), this was determined by the students (self-selection) to increase satisfaction with this learning method.

4. Evaluation of performance: for the purpose of this investigation, we summarized the evaluations of group work performance described in the literature as teacher's evaluation and peers' evaluation (Joyce, 2001; Joyce \& Elliot, 2007).

While the number of members, duration of the group and the process of defining the group remain constants, the type of evaluation was a variable manipulated: each type of evaluation was tested in three different years with different students.

Our hypothesis were i) that the group work learning method increased the overall satisfaction in teacher skills and in the course, and ii) that the peers' evaluation would produce the highest students' satisfaction with group work learning method.

In order to avoid students' evaluation and satisfaction being mainly related to the content of the course, rather than to the learning methods used, the results were compared to those reported by students who completed the course without the use group work learning method (control group). We analysed the questionnaire used by the University to measure students' satisfaction and evaluations of the course. Data were used to report means and a regression model was used to determine the interactions of the variables (satisfaction in teacher skills and in the course), which were the different types of evaluation: group performance by teacher, and group performance by teacher and by peers. 


\section{METHOD}

\section{Participants}

Overall, participants were 187 students of the Faculty of Psychology of the Università di Torino taking the course "Psychology of Mobbing, Harassment and Stalking" (30 hours per 6 credits). Overall $84.5 \%$ of them were females (confirming the national trend), and the average age was 24.06 years (range 21-47). One of this paper's authors was teaching the course. Two performances were required to conduct group work. During three different years, we adopted the group work methodology using three different evaluation systems (overall teacher's evaluation of the group performances [A course], overall teacher's and students' evaluation of the performances [B course], two teacher's and students' evaluation of the performance [C course]).

Each group was composed of different students (thus, the students who participated in this specific course did not take it in the following year). However, the groups were equivalent for gender and age. In course A, participants were 32 students, $2(6.3 \%)$ male and $30(93.8 \%)$ female, aged on average 23.65 years (range 22-29). In course B, participants were 72 students, $9(12.5 \%)$ male and $60(83.3 \%)$ female $(4.2 \%$ of students did not give any answer), aged on average 24.79 years (range 22-42). In course $C$, there were 42 students, $7(16.7 \%)$ male and $35(83.3 \%)$ female, aged on average 23.74 years (range 21-47). The control group consisted of 41 students, 8 (19.5\%) male and 33 (80.5\%) female; the average age was 23.75 years (range $21-33$ ). For all students, the credits required for attending the course was the same $(>120)$.

\section{Materials}

The questionnaire was created by the University of Torino to evaluate students' satisfaction with each individual course. This questionnaire is completed at the end of the course by each student taking the course. The aggregate data were sent to each teacher of the course. The first page of the questionnaire requested information about the socio-personal data of each participant (e.g., sex, age, city of residence, diploma). This was followed by 12 questions (see table 1) about the satisfaction in course (items 1, 2, 6 and 11), the teacher skills (items 3,8,9 and 10), the study load (namely the complexity of the task, item 4), the preliminary knowledge (item 5), supplementary teaching activities (item 7). The last question was about the overall satisfaction (item 12). There were four possible response options ("definitely dissatisfied", "more dissatisfied than satisfied", "more satisfied than dissatisfied", "definitely satisfied"). The questionnaire was anonymous and was administered at the end of the course by other students (not taking this specific course) who were trained for that duty. Teachers were not present during the administration of the questionnaire. The questionnaire was the same in each year.

The data from University management were presented in aggregate form. Consequently, socio-demographical data for each student were not available to teachers: Italian privacy law avoids identifying participants to the course instructors. Data from the questionnaire were presented in the four responses provided by students and in dichotomized form: 
dissatisfied or satisfied. The internal consistency of the questionnaire was Cronbach's alpha $=0.98$.

\section{Procedure}

At the beginning of each course, the teacher introduced the group work learning method and the evaluation of the performance. Because the duration of the course was five weeks, groups were intended to be short-term. Students were asked to form groups to describe and analyse two case studies (case 1 and case 2) that showed violent behaviors in the workplace and then to suggest a clinical (e.g., individual or group therapy) and organizational (e.g., training course) intervention. Goals and materials used in case 1 and 2 were the same in all groups. Two performances were required to perform group work. During three different years, we adopted the group work methodology using three different evaluation systems.

Students in course A were invited to choose the members of their group (from four to eight people) and the teacher evaluated the overall performances of group work (case 1 and 2). Students in course B were asked to form a group using the same criteria adopted in course A, but the teacher and the peers evaluated the group's overall performances for cases 1 and 2. Students in course $\mathrm{C}$ were asked to form a group using the same criteria adopted in course A and B previously described, but they were evaluated based on both group performances (case 1, case2) by the teacher and by peers. Thus, in course B and C each student could contribute to the evaluation of the other groups' performances, giving grades that were as important as the teacher's evaluation. In course $\mathrm{C}$ groups received an evaluation by teacher and peers for performance in case 1 , and an evaluation by teacher and peers for performance in case 2. To sum up:

- Course A, 32 students: case studies $(1,2)$ - (size ( $\leq 8)$-composition (students' decision: 8 groups total) - evaluation (by teacher on overall performances)

- Course B, 72 students: case studies $(1,2)$ - size $(\leq 8)$-composition (students' decision: 12 groups total) - evaluation (by teacher and peers on overall performances)

- Course C, 42 students: case study 1 and case 2- size ( $\leq 8)$ - composition (students' decision: 7 groups total) - evaluation (by teacher and by peers on performance both in case 1 and in case 2).

For the control group (41 students), the cases $(1,2)$ were presented and discussed by the teacher during the course (the duration of the course was the same: 5 weeks, 30 hours). No evaluation was provided for this activity.

Statistical analyses were performed using the statistical software SPSS, version 20. Descriptive measures (means $\pm \mathrm{SD}$ ) were calculated for all test variables for all groups of participants. Correlations were calculated to examine the relationship between the evaluation of students' overall satisfaction (item 12) and the other questions about the course, the teacher skills, the study load, the preliminary knowledge, supplementary teaching activities. Multiple linear regression analysis was performed with the students' overall satisfaction (item 12) as the dependent variable with the evaluation of the course, 
the teacher skills, the study load, the preliminary knowledge, and supplementary teaching activities as explanatory variables.

\section{FINDINGS}

\section{Descriptive analysis}

Data presented in tables 1, 2, 3 and 4 showed the students' degree of satisfaction with the course, teacher's skills, study load, preliminary knowledge, supplementary activities and overall satisfaction.

Table 1

Course A: students' satisfaction

\begin{tabular}{|c|c|c|c|c|c|c|c|}
\hline & $\begin{array}{c}\text { Definitely } \\
\text { dissatisfied }\end{array}$ & $\begin{array}{c}\text { More } \\
\text { dissatisfied } \\
\text { than satisfied }\end{array}$ & Dissatisfied & $\begin{array}{l}\text { More satisfied } \\
\text { than dissatisfied }\end{array}$ & $\begin{array}{c}\text { Definitely } \\
\text { satisfied }\end{array}$ & Satisfied & $\begin{array}{l}\text { Missing } \\
\text { items }\end{array}$ \\
\hline $\begin{array}{l}\text { 1. The structure of } \\
\text { the exam is clear }\end{array}$ & 9.4 & 15.6 & 25.0 & 53.1 & 21.9 & 75.0 & - \\
\hline $\begin{array}{l}\text { 2.Adherence to class } \\
\text { timetable }\end{array}$ & 0.0 & 6.3 & 6.3 & 34.4 & 59.4 & 93.7 & - \\
\hline $\begin{array}{l}\text { 3. Teacher is } \\
\text { available }\end{array}$ & 0.0 & 9.4 & 9.4 & 40.6 & 43.8 & 84.4 & 6.2 \\
\hline $\begin{array}{l}\text { 4. Study load is } \\
\text { adequate to credits } \\
\text { assigned }\end{array}$ & 9.4 & 6.3 & 15.7 & 40.6 & 40.6 & 81.2 & 3.1 \\
\hline $\begin{array}{l}\text { 5. Preliminary } \\
\text { knowledge is } \\
\text { adequate }\end{array}$ & 3.1 & 28.1 & 31.2 & 34.4 & 34.4 & 68.8 & - \\
\hline $\begin{array}{l}\text { 6. Learning material } \\
\text { is adequate }\end{array}$ & 6.3 & 12.5 & 18.8 & 37.5 & 43.7 & 81.2 & \\
\hline $\begin{array}{l}\text { 7. Supplementary } \\
\text { teaching activities }\end{array}$ & 3.1 & 9.4 & 12.5 & 34.4 & 25.0 & 59.4 & 28.1 \\
\hline $\begin{array}{l}8 . \text { Teacher } \\
\text { motivates interest }\end{array}$ & 12.5 & 3.1 & 15.6 & 40.6 & 43.8 & 84.4 & - \\
\hline $\begin{array}{l}\text { 9. Teacher explain } \\
\text { clearly }\end{array}$ & 6.3 & 18.7 & 25.0 & 37.5 & 37.5 & 75.0 & - \\
\hline $\begin{array}{l}\text { 10.Teacher clearly } \\
\text { underlines topics }\end{array}$ & 9.4 & 9.4 & 18.8 & 40.6 & 40.6 & 81.2 & - \\
\hline $\begin{array}{l}11 . \text { The topic of the } \\
\text { course is interesting }\end{array}$ & 3.1 & 12.5 & 15.6 & 28.1 & 56.3 & 84.4 & - \\
\hline $\begin{array}{l}\text { 12. Overall } \\
\text { satisfaction }\end{array}$ & 6.3 & 12.5 & 18.8 & 53.1 & 28.1 & 81.2 & - \\
\hline
\end{tabular}

Table 2

Course B: students' satisfaction

\begin{tabular}{lccccccc}
\hline & $\begin{array}{c}\text { Definitely } \\
\text { dissatisfied }\end{array}$ & $\begin{array}{c}\text { More } \\
\text { dissatisfied } \\
\text { than satisfied }\end{array}$ & Dissatisfied & $\begin{array}{c}\text { More } \\
\text { satisfied than } \\
\text { dissatisfied }\end{array}$ & $\begin{array}{c}\text { Definitely } \\
\text { satisfied }\end{array}$ & $\begin{array}{c}\text { Satisfied Missing } \\
\text { items }\end{array}$ \\
\hline $\begin{array}{l}\text { 1. The structure of } \\
\text { the exam is clear }\end{array}$ & 1.4 & 20.8 & $\mathbf{2 2 . 2}$ & 51.4 & 25.0 & $\mathbf{7 6 . 4}$ & 1.4 \\
\hline $\begin{array}{l}\text { 2.Adherence to class } \\
\text { timetable }\end{array}$ & 1.4 & 0.0 & $\mathbf{1 . 4}$ & 34.7 & 62.5 & $\mathbf{9 7 . 2}$ & 1.4 \\
\hline 3. Teacher is & 0.0 & 2.8 & $\mathbf{2 . 8}$ & 58.3 & 33.3 & $\mathbf{9 1 . 6}$ & 5.6 \\
\hline
\end{tabular}




\begin{tabular}{|c|c|c|c|c|c|c|c|}
\hline available & & & & & & & \\
\hline $\begin{array}{l}\text { 4. Study load is } \\
\text { adequate to credits } \\
\text { assigned }\end{array}$ & 1.4 & 8.3 & 9.7 & 63.9 & 25.0 & 88.9 & 1.4 \\
\hline $\begin{array}{l}\text { 5. Preliminary } \\
\text { knowledge is } \\
\text { adequate }\end{array}$ & 8.3 & 26.4 & 34.7 & 50.0 & 13.9 & 63.9 & 1.4 \\
\hline $\begin{array}{l}\text { 6. Learning material } \\
\text { is adequate }\end{array}$ & 1.4 & 13.9 & 15.3 & 59.7 & 23.6 & 83.3 & 1.4 \\
\hline $\begin{array}{l}\text { 7. Supplementary } \\
\text { teaching activities }\end{array}$ & 1.4 & 8.3 & 9.7 & 51.4 & 30.6 & 82.0 & 10.3 \\
\hline $\begin{array}{l}8 . \text { Teacher } \\
\text { motivates interest }\end{array}$ & 8.3 & 13.9 & 22.2 & 38.9 & 36.1 & 75.0 & 2.8 \\
\hline $\begin{array}{l}\text { 9. Teacher explain } \\
\text { clearly }\end{array}$ & 2.8 & 8.3 & 11.1 & 37.5 & 48.6 & 86.1 & 2.8 \\
\hline $\begin{array}{l}\text { 10.Teacher clearly } \\
\text { underlines topics }\end{array}$ & 4.2 & 8.3 & 12.5 & 48.6 & 36.1 & 84.7 & 2.8 \\
\hline $\begin{array}{l}\text { 11. The topic of the } \\
\text { course is interesting }\end{array}$ & 9.7 & 12.5 & 22.2 & 38.9 & 37.5 & 76.4 & 1.4 \\
\hline $\begin{array}{l}\text { 12. Overall } \\
\text { satisfaction }\end{array}$ & 9.7 & 8.3 & 18.0 & 48.7 & 31.9 & 80.6 & 1.4 \\
\hline
\end{tabular}

Table 3

Course C: students' satisfaction

\begin{tabular}{|c|c|c|c|c|c|c|c|}
\hline & $\begin{array}{c}\text { Definitely } \\
\text { dissatisfied }\end{array}$ & $\begin{array}{c}\text { More } \\
\text { dissatisfied } \\
\text { than satisfied }\end{array}$ & Dissatisfied & $\begin{array}{c}\text { More satisfied } \\
\text { than } \\
\text { dissatisfied }\end{array}$ & $\begin{array}{c}\text { Definitely } \\
\text { satisfied }\end{array}$ & Satisfied & $\begin{array}{l}\text { Missing } \\
\text { items }\end{array}$ \\
\hline $\begin{array}{l}\text { 1. The structure of } \\
\text { the exam is clear }\end{array}$ & 0.0 & 2.4 & 2.4 & 38.1 & 59.5 & 97.6 & - \\
\hline $\begin{array}{l}\text { 2.Adherence to } \\
\text { class timetable }\end{array}$ & 0.0 & 2.4 & 2.4 & 19.0 & 78.60 & 97.6 & - \\
\hline $\begin{array}{l}3 . \text { Teacher is } \\
\text { available }\end{array}$ & 0.0 & 2.4 & 2.4 & 47.6 & 50.0 & 97.6 & - \\
\hline $\begin{array}{l}\text { 4. Study load is } \\
\text { adequate to credits } \\
\text { assigned }\end{array}$ & 0.0 & 7.1 & 7.1 & 54.8 & 38.1 & 92.9 & - \\
\hline $\begin{array}{l}\text { 5. Preliminary } \\
\text { knowledge is } \\
\text { adequate }\end{array}$ & 7.3 & 31.7 & 39.0 & 39.0 & 22.0 & 61.0 & - \\
\hline $\begin{array}{l}\text { 6. Learning } \\
\text { material is adequate }\end{array}$ & 5.0 & 20.0 & 25.0 & 47.5 & 27.5 & 75.0 & - \\
\hline $\begin{array}{l}\text { 7. Supplementary } \\
\text { teaching activities }\end{array}$ & 5.9 & 11.8 & 17.7 & 35.3 & 47.0 & 82.3 & - \\
\hline $\begin{array}{l}8 \text { Teacher } \\
\text { motivates interest }\end{array}$ & 14.3 & 11.9 & 26.2 & 50.0 & 23.8 & 73.8 & - \\
\hline $\begin{array}{l}\text { 9. Teacher explain } \\
\text { clearly }\end{array}$ & 7.1 & 9.5 & 16.6 & 52.4 & 31.0 & 83.4 & - \\
\hline $\begin{array}{l}\text { 10.Teacher clearly } \\
\text { underlines topics }\end{array}$ & 4.9 & 19.5 & 24.4 & 43.9 & 31.7 & 75.6 & - \\
\hline $\begin{array}{l}\text { 11. The topic of the } \\
\text { course is interesting }\end{array}$ & 9.5 & 14.3 & 23.8 & 42.9 & 33.3 & 76.2 & - \\
\hline $\begin{array}{l}\text { 12. Overall } \\
\text { satisfaction }\end{array}$ & 11.9 & 9.5 & 21.4 & 40.5 & 38.1 & 78.6 & - \\
\hline
\end{tabular}

International Journal of Instruction, July $2017 \bullet$ Vol.10, No.3 
Table 4

Course without group work learning method (control group): students' satisfaction

\begin{tabular}{|c|c|c|c|c|c|c|c|}
\hline & $\begin{array}{c}\text { Definitely } \\
\text { dissatisfied }\end{array}$ & $\begin{array}{c}\text { More } \\
\text { dissatisfied } \\
\text { than satisfied }\end{array}$ & Dissatisfied & $\begin{array}{c}\text { More satisfied } \\
\text { than } \\
\text { dissatisfied }\end{array}$ & $\begin{array}{c}\text { Definitely } \\
\text { satisfied }\end{array}$ & Satisfied & $\begin{array}{c}\text { Missing } \\
\text { Items }\end{array}$ \\
\hline $\begin{array}{l}\text { 1. The structure of } \\
\text { the exam is clear }\end{array}$ & 19.5 & 9.8 & 29.3 & 34.1 & 36.6 & 70.7 & - \\
\hline $\begin{array}{l}\text { 2.Adherence to } \\
\text { class timetable }\end{array}$ & 0.0 & 7.3 & 7.3 & 46.3 & 46.3 & 92.6 & - \\
\hline $\begin{array}{l}3 . \text { Teacher is } \\
\text { available }\end{array}$ & 0.0 & 17.1 & 17.1 & 36.7 & 39.0 & 75.7 & - \\
\hline $\begin{array}{l}\text { 4. Study load is } \\
\text { adequate to credits } \\
\text { assigned }\end{array}$ & 2.4 & 17.1 & 19.5 & 41.5 & 39.0 & 80.5 & - \\
\hline $\begin{array}{l}\text { 5. Preliminary } \\
\text { knowledge is } \\
\text { adequate }\end{array}$ & 12.2 & 24.3 & 36.5 & 41.5 & 22.0 & 63.5 & - \\
\hline $\begin{array}{l}\text { 6. Learning } \\
\text { material is adequate }\end{array}$ & 12.2 & 34.1 & 46.3 & 29.3 & 24.4 & 53.7 & - \\
\hline $\begin{array}{l}\text { 7. Supplementary } \\
\text { teaching activities }\end{array}$ & - & - & - & - & - & - & - \\
\hline $\begin{array}{l}\text { 8. Teacher } \\
\text { motivates interest }\end{array}$ & 22.0 & 46.3 & 68.3 & 26.8 & 4.9 & 31.7 & - \\
\hline $\begin{array}{l}\text { 9. Teacher explain } \\
\text { clearly }\end{array}$ & 9.8 & 34.1 & 43.9 & 46.3 & 9.8 & 56.1 & - \\
\hline $\begin{array}{l}\text { 10.Teacher clearly } \\
\text { underlines topics }\end{array}$ & 9.8 & 26.8 & 36.6 & 56.1 & 7.3 & 63.4 & - \\
\hline $\begin{array}{l}\text { 11. The topic of the } \\
\text { course is interesting }\end{array}$ & 19.5 & 46.3 & 65.8 & 31.8 & 2.4 & 34.2 & - \\
\hline $\begin{array}{l}\text { 12. Overall } \\
\text { satisfaction }\end{array}$ & 22.0 & 24.4 & 46.4 & 43.9 & 7.3 & 51.2 & 2.4 \\
\hline
\end{tabular}

Course A students evaluated the course as "satisfied" in all items $(1,2,6,11$; table 1). Course B students evaluated the same items as "satisfied", thought the item 11 received an evaluation of less positive (table 2). In course $\mathrm{C}$, the item about the course received a more positive evaluation (table 3). The evaluation of the item 6 is more negative than these attributed by students in course A and B; the item 11 is similar to these attributed by course B students. In control group, the items about the course were evaluated as more "dissatisfied" than A, B and C courses (see table 4). The teacher skills (items 3, 8, $9,10)$, in the course A students evaluated the item 8 more positively, while in course B students appreciated the skill to underline topics (item 10) more than the students in course A and C. In course C, students evaluated the availability of the teacher (item 3) more positively. In control group, this topic was generally evaluated as less satisfied, in particular for the teacher's skill to motivate interest (item 8; table 4). About the study load (item 4), the course C students evaluated the workload more positively than students in course A, B and control group. Preliminary knowledge (item 5) was more positively evaluated by students in course A than the students participating in course B, $\mathrm{C}$ and control group. Supplementary teaching activities (item 7) were evaluated more positively by students in course $\mathrm{C}$ than the students attending the course A and B. This 
item obviously did not occur in the control group. The overall satisfaction with the course (item 12) received a more positive evaluation in course B than in course A and C, while almost half of the students in control group attributed to "dissatisfied" and half of them to "satisfied".

\section{Inferential statistics}

The correlation matrix showed a significant correlation between overall students' satisfaction (item 12) and item $4(r=0.95, p<0.05)$ but only in Course C. It seems that in course $\mathrm{C}$, where the complexity of the task increased (two performances, two evaluations each), students perceived that the number of credits assigned to the course became more appropriate for the required study load.

Multiple linear regression analysis showed that in A and B courses the students' overall satisfaction was correlated with the item 11 (respectively R2 $=.60, F=11.99, p<0.001$ and $\mathrm{R} 2=.64, F=8.23, p<0.001)$. In $\mathrm{C}$ course, students' overall satisfaction was correlated with the items $7(p<0.05), 9(p<0.05)$ and $11(p<0.05)(\mathrm{R} 2=.85, F=11.79$, $p<0.001)$.

\section{DISCUSSION}

The aim of this study was to contribute to our understanding of whether group work learning method and which type of evaluation of performance are satisfactory for students. Findings showed that the group work learning method increased the overall satisfaction in teacher skills and in the course: the A, B and C courses received highest scores in overall satisfaction and satisfaction in course, teacher skills and study load than in the control group (tables 1-4). This means that the group work learning method permits to improve the satisfaction to the course, and to the teacher skills such as her/his ability to teach. Thus, the first hypothesis was confirmed. Furthermore, the second hypothesis was confirmed: the highest score in satisfaction with supplementary teaching activities was attributed to the course $\mathrm{B}$ and $\mathrm{C}$, in which the evaluation was made by teacher and peers. In course $\mathrm{C}$ students had the opportunity to be evaluated for two performances (case 1 and case 2): this permits to receive first feedback in case 1 that help the group to improve their skills and try to perform better in case 2 . Those findings are in line with those from Joyce (2001) and Joyce and Elliot (2007), regarding the students' preference for peer evaluation.

An interesting result concerns the teacher's ability to stimulate interest, and students' interest in the topic. For each question, students' satisfaction was higher in course A, where the assigned grade depended exclusively on the teacher's evaluation. As suggested by Burdett (2007), the teacher's evaluation of individuals allows students to avoid conflicts with their peers. Another interesting result concerns the adequacy of the workload related to credits assigned: the highest ratings were given to course C. It seems that when the complexity of the task increased, students perceived the number of credits assigned to the course as more appropriate. It is possible that when students work in groups, the workload is shared with others, and this situation may be easier for the less motivated students, who could benefit from the contributions of the more active members of the group. 
Some limits of this research should be mentioned. First, the data provided by the University's management were not complete. For example, socio-demographic information was provided only in an aggregate way (to respect Italian privacy law), so we did not have information that would allow further statistical analysis. Second, the questionnaire was tailored by the University to investigate the students' satisfaction with the course (e.g., the teacher's ability to stimulate, the supplementary teaching activities) but was not intended to evaluate, in depth, the single activity proposed during the course. Future researches should use more sophisticated instruments - see the investigation conducted by Hamlyn-Harris et al (2006) and Lovell and Nunnery (2004) - to describe the students' satisfaction with group work learning method and the different evaluation approaches of group performance.

Despite these limitations, this study confirms that students' satisfaction increases when this method is used. Group work learning method is a pedagogical method that permits practical teaching of not only a specific subject but also of important transferable professional skills (Topping, 2010) such as working in a group, the achievement of a goal, cooperation, and the sharing of ideas (Blackshaw \& Latu, 2005). Since students' satisfaction has become a critical indicator of teaching quality and - consequently - of the quality of educational institution, teachers could benefit from the results of this research. For example, in designing programs that include group work learning method and an adequate evaluation of the group performance (by teacher and by peers). Inclusion of this method allows teachers to increase educational effectiveness and allows students to learn transferable professional skills.

\section{REFERENCES}

Blackshaw, B., \& Latu, S. (2005). Group work and group work assessment for computer courses: A systems analysis and design case study. Proc. 16th Australasian Conference on Information Systems, Sydney, Australia.

Bonanno, H., Jones, J., \& English, L. (1998). Improving group satisfaction: Making groups work in a first-year undergraduate course. Teaching in Higher Education, 3(3), 365-382. doi:10.1080/1356215980030306.

Bradley, J., White, B. J., \& Mennecke, B. E. (2003). Teams and tasks a temporal framework for the effects of interpersonal interventions on team performance. Small Group Research, 34(3), 353-387. doi: 10.1177/1046496403034003004

Burdett, J. (2007). Degrees of separation-Balancing intervention and independence in group work assignments. The Australian Educational Researcher, 34(1), 55-71. doi:10.1007/BF03216850

Elliott, N., \& Higgins, A. (2005). Self and peer assessment-does it make a difference to student group work?. Nurse Education in Practice, 5(1), 40-48. doi:10.1016/j.nepr.2004.03.004 
Hamlyn-Harris, J., Hurst, B., Von Baggo, K., \& Bayley, A. (2006). Predictors of team work satisfaction. Journal of Information Technology Education: Research, 5(1), 29931 .

Hillyard, C., Gillespie, D., \& Littig, P. (2010). University students' attitudes about learning in small groups after frequent participation. Active Learning in Higher Education, 11(1), 9-20. doi: 10.1177/1469787409355867

Johnson, D. W., \& Johnson, R. T (1992). Positive interdependence: Key to effective cooperation. In R. Hertz-Lazarowitz \& N. Miller (Eds) Interaction in cooperative groups: The theoretical anatomy of group learning. (pp 174-199). Cambridge: University Press.

Johnson, D. W., Johnson, R. T., \& Smith, K. A. (2014). Cooperative learning: Improving university instruction by basing practice on validated theory. Journal on Excellence in University Teaching, 25(4), 1-26.

Johnson, D.W., Johnson, R.T., \& Stanne, M.B. (2000). Cooperative Learning Methods: A Meta-Analysis. University of Minnesota, Minneapolis: Cooperative Leaming Center.

Joyce, D. (2001). Managing and assessing group work at postgraduate level. Proc. 14th Annual Conference of the National Advisory Committee on Computing Qualifications. Napier, NZ: NACCQ

Joyce, D., \& Elliot, S. (2007). Assessed group work: Staff and student perspectives. Paper presented at the 20th Annual Conference of the National Advisory Committee on Computing Qualifications. Nelson, NZ: NACCQ

Kamin, C., O'Sullivan, P., Deterding, R., \& Younger, M. (2003). A comparison of critical thinking in groups of third-year medical students in text, video, and virtual PBL case modalities. Academic Medicine, 78(2), 204-211.doi: 10.1097/00001888200302000-00018

Leeds, M., Stull, W., \& Westbrook, J. (1998). Do changes in classroom techniques matter? Teaching strategies and their effects on teaching evaluations. Journal of Education for Business, 74(2), 75-78. doi:10.1080/08832329809601665

Letcher, D. W., \& Neves, J. S. (2010). Determinants of undergraduate business student satisfaction. Research in Higher Education Journal, 6, 1.

Lovell, C. W., \& Nunnery, J. (2004). Testing the adult development Tower of Babel hypothesis: Homogeneous by Perry position collaborative learning groups and graduate student satisfaction. Journal of Adult Development, 11(2), 139-150. doi: 10.1023/B:JADE.0000024546.27564.9c

MacQuarrie, S., Howe, C., Boyle, J. (2012). Exploring the characteristics of small groups within science and English secondary classrooms, Cambridge Journal of Education, 42(4), 527-546. doi: 10.1080/0305764X.2012.733345 
Moore, A. (Ed.). (2006). Schooling, Society And Curriculum. New York, NY: Routledge.

Moreland, R. L., Levine, J. M., \& Wingert, M. L. (1996). Creating the ideal group: Composition effects at work. In J. Davis \& E. Witte (Eds.), Understanding group behavior (Vol. 2, pp. 11-35). Hillsdale, NJ: Erlbaum.

Pang, E., \& Hung, H. (2016). Learning effectiveness and satisfaction in study groups: A consideration of the moderating factors. Educare, 5(1).

Pedro, E., Leitão, J., \& Alves, H. (2016). Does the quality of academic life matter for students' performance, loyalty and university recommendation? Applied Research in Quality of Life, 11(1), 293-316.doi: 10.1007/s11482-014-9367-6

Salako, E.C., Eze, I.R., \& Adu, E.O., (2013), Effects of cooperative learning on junior secondary school students' knowledge and attitudes to multicultural education concepts in social studies. Education, 133(3), 303-309

Sullivan, F. R., \& Wilson, N. C. (2015). Playful talk: Negotiating opportunities to learn in collaborative groups. Journal of the Learning Sciences, 24(1), 5-52. doi: $10.1080 / 10508406.2013 .839945$

Tessema, M. T., Ready, K., \& Yu, W. (2012). Factors affecting college students' satisfaction with major curriculum: Evidence from nine years of data. International Journal of Humanities and Social Science, 2(2), 34-44.

Topping, K. (2003). Self and peer assessment in school and university: Reliability, validity and utility. In M. Segers, F. Dochy \& E. Cascallar (Eds.) Optimising new modes of assessment: In search of qualities and standards (pp. 55-87). Springer Netherlands: Kluwer Academic Publisher.

Topping, K. J. (2010). Methodological quandaries in studying process and outcomes in peer assessment. Learning and Instruction, 20(4), 339-343. doi: 10.1016/j.learninstruc.2009.08.003 


\section{Turkish Abstract}

Grup çalışması yönteminde öğrenci memnuniyeti ve performanslarının değerlendirilmesi: İtalyan Üniversitesi'nde bir araştırma

Grup çalışmasıyla öğrenme yöntemi, öğrencilerin hem bilişsel hem de sosyal yeteneklerini arttıran öğrencilerin aktif bir şekilde katılımına olumlu katkı sağlayan işbirliğine dayalı bir öğrenme şeklidir. Kursun içeriği, aynı çalışma ortamında bulunan, şiddet davranışları gösteren iki grubun öğrencilerine ilişkin yaratıcı çözümler bulmak amacıya gönüllülk esasına dayalı olarak seçilmiştir. $\mathrm{Bu}$ araştırmada memnuniyete ilişkin etkinlikler ve etkinliklerdeki performans değerlendirme yöntemleri incelenmiştir. Bulgular bütün öğrencilerin grup çalışması yöntemiyle öğrenme etkinliklerindeki memnuniyetlerini dğrulamıştır. Bu memnuniyet kursta elde ettikleri notlarını ve öğretmen beceri memnuniyetini geliştimiştir. Değerlendirme ile ilgili bulgular ise öğrencilerin öğretmenlerin ve sınıf arkadaşlarının değerlendirme performanslarıyla aynı fikirde olduğunu göstermiştir.

Anahtar Kelimeler: memnuniyet, değerlendirme, katılım, psikoloji, öğrenme, İtalya

\section{French Abstract}

La satisfaction d'Étudiants de la méthode de travail en groupe et son évaluation de performance : une enquête dans une Université Italienne

Le travail en groupe Apprenant la Méthode est une coopérative apprenant la technique qui a des effets positifs dans l'apprentissage : la participation active des étudiants peut augmenter compétences tant cognitives que sociales. Le contenu du cours était le même dans toutes les années, on a demandé aux étudiants de former des groupes auto-choisis pour trouver des solutions créatives de deux casquant au comportement violent dans le lieu de travail. La satisfaction concernant cette activité et la méthode d'évaluer la performance de l'activité a été examinée. Les découvertes confirment la satisfaction des étudiants globaux liée au travail en groupe apprenant la méthode. Cette satisfaction améliore le grand nombre dans le cours et la satisfaction de compétences de professeur. De l'évaluation, des découvertes montrées que les étudiants ont accepté l'évaluation du professeur et pairs(égaux) de la performance.

Mots Clés: satisfaction, évaluation, participation, psychologie, apprentissage, l'Italie

\section{Arabic Abstract}

قناعة الطلاب مع منهج عمل المجموعة وتقييم أدائها: دراسة استقصائية في الجامعة الإيطالية

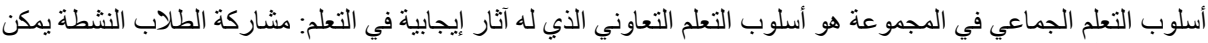

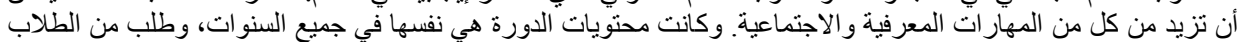

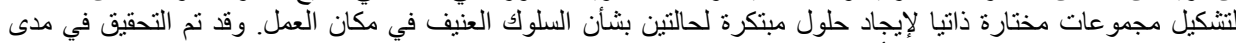

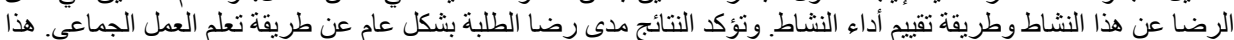

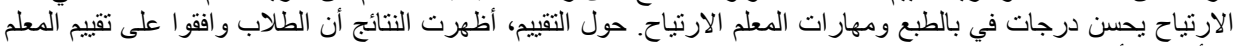

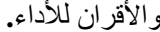

الكلمات المفتاحية: القناعة، التقييم، المشاركة، علم النفس، التعلم، إيطاليا

International Journal of Instruction, July $2017 \bullet$ Vol.10, No.3 


\section{German Abstract \\ Die Zufriedenheit der Studierenden mit der Gruppenarbeit und ihre Leistungsbewertung: Eine Umfrage in einer italienischen Universität}

Gruppenarbeit Lernmethode ist eine kooperative Lerntechnik, die positive Effekte beim Lernen hat: Die aktive Teilnahme der Schüler kann sowohl kognitive als auch soziale Fähigkeiten erhöhen. Die Inhalte des Kurses waren in allen Jahren gleich, die Schüler wurden gebeten, selbst ausgewählte Gruppen zu bilden, um kreative Lösungen für zwei Fälle zu finden, die ein gewalttätiges Verhalten am Arbeitsplatz betreffen. Die Zufriedenheit über diese Tätigkeit und die Methode zur Bewertung der Leistungsfähigkeit der Aktivität wurden untersucht. Befunde bestätigen die Zufriedenheit der Studenten im Zusammenhang mit der Gruppenarbeit Lernmethode. Diese Zufriedenheit verbessert die Punktzahl in Kurs und Lehrer Fähigkeiten Zufriedenheit. Über die Auswertung zeigten die Ergebnisse, dass die Schüler die Auswertung der Leistung der Lehrer und Peers verabschiedeten.

Schlüsselwörter: zufriedenheit, bewertung, teilnahme, psychologie, lernen, Italien

\section{Malaysian Abstract \\ Kepuasan Pelajar Dengan Kaedah Kerja Berkumpulan Dan Penilaian Prestasi: Satu Kajian Di Sebuah Universiti Itali}

Kaedah Pembelajaran berkumpulan adalah satu teknik pembelajaran koperatif yang mempunyai kesan positif dalam pembelajaran: penyertaan aktif pelajar boleh meningkatkan kedua-dua kemahiran kognitif dan sosial. Kandungan kursus ini adalah sama dalam semua tahun, pelajar diminta untuk membentuk kumpulan sendiri yang dipilih untuk mencari penyelesaian kreatif untuk dua kes mengenai kelakuan keganasan di tempat kerja. Kepuasan mengenai aktiviti ini dan kaedah untuk menilai prestasi aktiviti yang telah dikaji. Penemuan mengesahkan kepuasan keseluruhan pelajar yang berkaitan dengan kaedah pembelajaran kerja kumpulan. Kepuasan ini meningkatkan skor dalam kursus dan kemahiran guru kepuasan. Berkaitan penilaian, penemuan menunjukkan bahawa pelajar bersetuju guru dan rakan sebaya penilaian prestasi.

Kata Kunci: kepuasan, penilaian, penyertaan, psikologi, pembelajaran, Italy

\section{Russian Abstract \\ Удовлетворенность Студентов Методом Групповой Работы и Его Оценкой Эффективности: Опрос в Итальянском Университете}

Метод групповой работы, является кооперативным методом обучения и оказывает положительное воздействие на процесс обучения: активное участие студентов может повысить как когнитивные, так и социальные навыки. Содержание курса было одинаковым во все годы. Студентов попросили самостоятельно выбрать группы, чтобы найти творческие решения по двум случаям, связанным с жестоким поведением на рабочем месте. Были изучены удовлетворенность этой деятельностью и метод оценки эффективности деятельности. Результаты подтверждают общую удовлетворенность учащихся работой в группах. Это удовлетворение улучшает оценку в курсе и удовлетворенность навыками преподавателя. Результаты показали, что учащиеся согласились с оценкой учителей.

Ключевые Слова: удовлетворение, оценка, участие, психология, обучение, Италия 